\title{
AMS NOTICES
}

NOMINATION SUBMISSIONS

The Council of the American Meteorological Society invites members of the AMS to submit nominations for consideration by the committees listed below. The names of all individuals nominated, together with background data on the individuals, should be sent to the appropriate committee in care of the Secretary-Treasurer, American Meteorological Society, 45 Beacon Street, Boston, MA 02108-3693.*

The specifications for all awards are set forth in the August 1998 Bulletin, starting on page 1584.

\section{Nominating Committee}

The Committee's function is to submit to the Council the names of individuals for 1) the office of President-Elect for a term of one year starting at the close of the 80th Annual Meeting (January 2000), and 2) four positions on the Council for a term of three years starting at the close of the Annual Meeting. Nominations must be submitted prior to 1 April 1999 to the Nominating Committee. ${ }^{+}$

\section{Committee on Fellows}

The Committee's function is to submit to the Council the names of individuals for election to Fellow.

Article III, Section 6, of the AMS Constitution provides that those eligible for election to Fellow shall have made outstanding contributions to the atmospheric or related oceanic or hydrologic sciences or their applications during a substantial period of years The names of nominees for Fellow remain on the Committee's active list for three years. A nomination form, which is available on request from AMS headquarters, should be used.

Nominations for Fellow must be submitted prior to 1 June 1999 (limited to one page) to the Committee on Fellows. ${ }^{+}$

\section{The Sverdrup Gold Medal}

Unlike other awards, the Sverdrup Medal is awarded by the President of the Society on the advice of an international committee. Nominations for the award with supporting documentation must be submitted prior to 1 May 1999 to the Sverdrup Gold Medal Committee. $^{+}$

\section{The Henry Stommel Research Award}

Nominations for the award with supporting documentation must be submitted prior to 1 May 1999 to the Henry Stommel Research Award Committee. ${ }^{+}$The Committee will submit the name of the individual selected to the Council for their approval.

*Please note that deadlines differ.

${ }^{+}$Care of the Secretary-Treasurer, American Meteorological Society, 45 Beacon Street, Boston, MA 02108-3693.

\section{Awards Committee}

The Committee's function is to submit to the Council the names of individuals for the Society's awards. The names of the nominees for awards remain on the Awards Committee's active list for three years. Nominations must be submitted before 1 June 1999 to the Awards Committee. ${ }^{+}$

The Society's awards are:

- The Carl-Gustaf Rossby Research Medal

- The Jule G. Charney Award

- The Verner E. Suomi Award

- The Charles Franklin Brooks Award for Outstanding Services to the Society

- The Cleveland Abbe Award for Distinguished Service to the Atmospheric Sciences by an Individual

- The Meisinger Award

- The Henry G. Houghton Award

- The Award for Outstanding Services to Meteorology by a Corporation

- The Louis J. Battan Author's Award

Nominations for the following eight awards are submitted to the committee shown below. The committee submits a recommendation to the commissioner, who reviews it and makes a recommendation to the Council. Nominations for these awards with supporting documentation should be sent to the appropriate committee prior to 1 May 1999.

\section{The Award for Outstanding Service by a Weather Forecaster}

- The Charles L. Mitchell Award for long-term service by persons engaged in weather forecasting activities

- The Award for an Exceptional Specific Prediction

- The Francis W. Reichelderfer Award for distinguished public service contributions by personnel of the weather service

Submit documentation to the AMS Committee on Weather Analysis and Forecasting with a copy to the STAC commissioner.

\section{The Award for Outstanding Contribution to the Advance of Applied Meteorology}

Submit documentation to the AMS Board of Private Sector Meteorology with a copy to the professional affairs commissioner. ${ }^{+}$

\section{The Award for Outstanding Service by a Broadcast Meteorologist}

Submit documentation to the AMS Board of Broadcast Meteorology with a copy to the professional affairs commissioner. ${ }^{+}$ 


\section{AMS NOTICES}

\section{NOMINATION SUBMISSIONS}

\section{The Award for Outstanding Achievement in} Biometeorology

Submit documentation to the Committee on Biometeorology and Aerobiology with a copy to the STAC commissioner. ${ }^{+}$

\section{The Robert Leviton Award}

Submit documentation to the AMS Committee on Measurements with a copy to the STAC commissioner. ${ }^{+}$

\section{The Banner I. Miller Award}

Submit documentation to the Committee on Tropical Meteorology and Tropical Cyclones with a copy to the STAC commissioner. $^{+}$

${ }^{+}$Care of the Secretary-Treasurer, American Meteorological Society, 45 Beacon Street, Boston, MA 02108-3693.

**In care of Lectureships, American Meteorological Society, 45 Beacon St., Boston, MA 02108. Documentation should be in the form of a one-page letter describing the qualifications of the nominee (or other appropriate nomination document).

\section{LECTURE NOMINATIONS}

Nominations for the following four lectureships should be submitted before 1 October 1999 to the committee(s) shown below and the STAC commissioner.

\section{The Robert E. Horton Lecturer in Hydrology}

Submit documentation to the Committee on Hydrology.**

\section{The Bernhard Haurwitz Memorial Lecturer}

Submit documentation to the Atmospheric and Oceanic Waves and Stability, Middle Atmosphere, or Climate Variations Committees.**

\section{The Remote Sensing Lecturer}

Submit documentation to the Radar, Satellite, Laser, Atmospheric Radiation, or Measurements Committees.**

The Walter Orr Roberts Lecturer in Interdisciplinary Sciences

Submit documentation to the chairperson of any STAC committee.**

\section{Visit AMS ON THE World Wide Web}

\section{FOR THE LATEST INFORMATION ABOUT THE Americay Meteorological Society, ITS ACTIVITIES, AND ITS PUBLICATIONS}

You'll find our Web site located at:

\section{http://www.ametsoc.org/AMS}

